\title{
Organisational culture aspects that facilitate lean implementation: a pilot study
}

\author{
Abdullah Alkhoraif* and Patrick McLaughlin \\ Manufacturing Department, \\ School of Aerospace, Transport and Manufacturing, \\ Cranfield University, \\ Cranfield, Bedfordshire, \\ MK43 0AL, UK \\ Email: a.a.alkhoraif@cranfield.ac.uk \\ Email: p.mclaughlin@cranfield.ac.uk \\ *Corresponding author
}

\begin{abstract}
The paper aims to identify enablers and inhibitors of Lean Implementation (LI) in a small and medium-sized manufacturing (SME) organisation in Saudi Arabia. The paper opted for an exploratory study using the semi-structure interview approach of grounded theory, including seven in-depth interviews with employees representing from top management to the workers in the workshop having mainly an experience of Lean Implementation background. The data was complemented by context analysis, including simultaneous and concurrent data collection and constant comparison methods. It suggests successful communication and teamwork. However, there were two codes which had not been evidenced in prior research and were not identified in the literature review. These include; 'multiple decision makers' and the 'family effect'. This paper fulfils an identified need to study how organisational culture affects LI. It demonstrates the current state of LI in manufacturing companies by uncovering the enablers and inhibitors of organisational culture.
\end{abstract}

Keywords: organisational culture; OC; lean implementation; LI; enablers and inhibitors; small and medium-sized enterprises; SMEs; pilot study.

Reference to this paper should be made as follows: Alkhoraif, A. and McLaughlin, P. (2018) 'Organisational culture aspects that facilitate lean implementation: a pilot study', Int. J. Agile Systems and Management, Vol. 11, No. 2, pp.103-125.

Biographical notes: Abdullah Alkhoraif is a PhD Researcher Assistant at the School of Aerospace Transportation and Manufacturing, Cranfield University. $\mathrm{He}$ holds BEng Engineering and Business and MSc Engineering Project Management form the Bournemouth University. Recently, he has published two books in The Process of Quality Material Selection and Contractual and Sub-Contractual Risks: Project Management Perspective. He was involved in the oil industry for ten years. The research presented in this article is part of the research project 'A Framework to Improve Lean Implementation by Leveraging Organisational Culture'. 
Patrick McLaughlin holds CEng, FIET, FIMechE, FHEA, MSc from the School of Aerospace Transportation and Manufacturing, Cranfield University. $\mathrm{He}$ is a Chartered Engineer and EurIng. He is a Fellow of both the Institution of Mechanical Engineers and the Institution of Engineering and Technology, as well as a Fellow of the Higher Education Academy. He has an MSc in Industrial Engineering and Production Management and a Doctorate in Business Administration (DBA), both from the Cranfield. He has worked at director level in manufacturing operations for over twenty years, and has been responsible for several plant-wide lean manufacturing implementations

\section{Introduction}

A pilot study is a "small scale version[s], or trial run[s], done in preparation for the major study" [Hungler et al., (2001), p.467]. The aim of the pilot study is to identify enablers and inhibitors of lean implementation (LI) in small and medium-sized manufacturing enterprises (SMEs) in Saudi Arabia. The study uses qualitative analysis in order to gain insights into organisational culture. Moreover, the purpose of this is to conduct issue focused semi-structured interviews with the sample group. A grounded theory methodology has been selected due to the nature of the research which involves exploring organisational culture aspects. The pilot study will involve only opens coding analyses which enables the identification of enablers and inhibitors of lean in organisational culture within a broader context. The findings identify the aspects which did not appear in literature review with regards to organisational culture, SMEs, thus informing the main research phase. Conducting a pilot study is important to explore and uncover aspects of inhibitors and enablers of lean in organisational culture of SMEs which do not appear in prior research. The information will then influence the direction of the future interviews to be conducted in the main study (Charmaz, 1995). For the purpose of this paper SMEs refers to organisations with fewer than 250 employees (European Commission definition adopted) (European Commission, 2011).

Implementing lean into manufacturing SMEs within Saudi Arabia faces difficulties, whereas it is more likely to be implemented successfully in larger companies, which then benefit from the advantages of lean systems (Karim et al., 2011). Moreover, the culture of an organisation plays a vital role, especially for managers facing the challenge to change that culture (Graham-jones and Muhareb, 2015). It is necessary to have a feasible Lean framework to assist SMEs to successfully implement lean (Pingyu and Yu, 2010).

Saudi Arabia's economy is dependent on oil and gas resources, forcing the government to find new non-oil sources. According to the IMF (Alshahrani and Alsadiq, 2014), the Kingdom of Saudi Arabia is regarded as a dominant economic force within the Middle East and the North African region (MENA).According to the Saudi Industrial Property Authority known as MODON (Saudi Industrial Property Authority, 2015), the Saudi Government has set up clusters in various regions of the kingdom and right now manages over more than 32 existing and under-developed cities. In addition, there are more cities currently being planned and designed. The number of these industrial cities shall reach 40, with more than 160 million square meters of developed industrial lands. There are more than 3,000 factories in the existing industrial cities employing over 300,000 members with investments exceeding 250 billion Saudi Riyals (SR). Moreover, 2,000 factories will be built for SMEs. Organisational culture is one of the most 
important factors in Saudi Arabia to focus on to facilitate the implementation of lean within Saudi Arabian manufacturing (Karim and Arif-Uz-Zaman, 2013). The main aim of this research is to develop an organisational culture framework for SA-SMMs to facilitate (LI) before adopting the lean system. According to Karim et al. (2011), the most important factor that affects the implementation of lean is the organisation's culture. It has been observed that the appropriate lean culture enhances the pace of growth and keeps the firm competitive (Pooyan et al., 2014).

\section{Lean philosophy}

The aim of lean production is that company resources should all be channelled in ways that ultimately create value for the end user (Schouteten and Benders, 2004). In essence it works towards the goal of maintaining value while doing less work and at the heart is achieving greater efficiency (Schouteten and Benders, 2004). The definition of Lean provided by Corbett (2007) emphasises on lean as an integral part of the entire organisation, essentially pointing to lean as being considered more of a philosophy than just a tool or process. This is further supported by Womack and Jones, (2003) who suggest that lean is becoming understood as more than just production, but an all-encompassing business ideology which incorporates all aspects of value streams as opposed to individual production processes. According to Bhamu and Singh Sangwan (2014), lean provides a methodology by which organisations can significantly improve their responsiveness to customers while decreasing and managing costs and waste in supply and operational procedures. The following table presents various definitions of lean.

Twenty years on since Womack, Jones and Roos's book release the success rate of lean is still rather low (Bhasin, 2012; Pay, 2008; Yamamoto and Bellgran, 2010). Chay et al. (2015) suggests it is complicated to implement lean by merely focusing on the hard aspect (tools) without also including the soft aspects. Chase (1999) emphasises the need to view lean as a long-term strategy. Lewis (2000) and Lin and Hui (1999) are more sceptical of lean while, Oliver and Hunter (1998) found no correlation between high and low users of lean and organisational performance. Shah and Ward (2007) suggest there is a lack of a common definition for lean. The absence of clarity can be seen from the vast amount of term used regarding Lean production (Shah and Ward, 2007). The ambivalence is in part due to Lean having evolved over a long-time period (Shah and Ward, 2007; Womack et al., 1991). Stone (2012) suggest the confusion surrounding what exactly lean means is partly what has led to misguided efforts in its implementation without encompassing its philosophy. Angelis et al. (2011, p.569) suggests that lean production is based on several key principles: eliminating wasteful activities, minimising process variability, pursuing continuous process improvement with employee involvement, devolvement of activities such a quality inspections and periodic maintenance to line workers and maintaining synchronised production flow through shop floor visual signals. Overall increased competition and a more globalised market place have led to stiffer competition with greater demands on businesses to succeed. Regarding demand, customers are presented with a great range of products and thus are growing more assertive and looking for greater value. Organisations can respond to this by improving their understanding of aspects valued by customers and exercising 
improvements in operations to deliver this (Hu et al., 2015). Thus, many companies have turned towards lean to help fulfil this challenge. At the heart of lean is being highly responsive to the needs of customers, while constantly looking to improve waste and cost management ( $\mathrm{Hu}$ et al., 2015). An interesting notion to consider in the definition provided above is listing the inclusion of pursuit of improvement with employee involvement (Allen and Meyer, 1993). One might consider that employee involvement is also somewhat dependent on the (OC) of the company (Angelis et al., 2011). Also, the autonomy given to employees and the existence of two way communication within the business (Alstrup, 2000).

Table 1 Lean definitions

\begin{tabular}{|c|c|}
\hline Definitions of lean & Reference \\
\hline $\begin{array}{l}\text { 'The lean approach percolates into ever wider circles of operations, it } \\
\text { ceases to be about the best practice and starts to become a part of the } \\
\text { fabric of doing business'. }\end{array}$ & Corbett $(2007$, p.96) \\
\hline $\begin{array}{l}\text { 'Lean production is based on several key principles: eliminating } \\
\text { wasteful activities, minimising process variability, pursuing continuous } \\
\text { process improvement with employee involvement, devolvement of } \\
\text { activities such a quality inspections and periodic maintenance to line } \\
\text { workers and maintaining synchronised production flow through shop } \\
\text { floor visual signals'. }\end{array}$ & $\begin{array}{l}\text { Angelis et al. } \\
(2011, \text { p.569) }\end{array}$ \\
\hline $\begin{array}{l}\text { 'Lean production is an integrated socio-technical system whose main } \\
\text { objective is to eliminate waste by concurrently reducing or minimising } \\
\text { supplier, customer and internal variability'. }\end{array}$ & $\begin{array}{l}\text { Shah and Ward } \\
(2007, \text { p.791) }\end{array}$ \\
\hline $\begin{array}{l}\text { 'Production that minimises buffering costs associated with excess lead } \\
\text { times, inventories, or capacity'. }\end{array}$ & $\begin{array}{l}\text { Hopp and Spearman } \\
\text { (2004) and Angelis } \\
\text { et al. (2011, p.569) }\end{array}$ \\
\hline $\begin{array}{l}\text { 'Lean manufacturing combines the capabilities of the workforce with } \\
\text { organisational techniques to achieve high outcomes with few } \\
\text { resources'. }\end{array}$ & $\begin{array}{l}\text { Salem et al. }(2006, \\
\text { p.169) }\end{array}$ \\
\hline
\end{tabular}

When looking at lean from a holistic perspective it is considered to greatly encourage organisational learning (Womack, et al 1990). It has been suggested that implementing Lean systems sets benchmarks enabling the measurement of performance. However, this is greatly dependent on the type of lean system design (Crofton and Dale, 1996). A study conducted in Volvo's Uddevalla automobile plant in Sweden found that 1 learning as much as others (Adler and Cole, 1995). They suggest that the New United Motor Manufacturing, Inc. (NUMMI) plant in California, a joint venture between GM Motors and Toyota outperformed Uddevalla in terms of performance. This was attributed to the ability to better knowledge sharing compared at NUMMI compared to Uddevalla which gained deeper knowledge which was kept within tight teams (Adler and Cole, 1995).

Organisational learning can be described as ways in which a company will seek to maintain and ameliorate their competitiveness, productivity and innovation meeting external environmental demands, resulting in a continued competitive advantage, (Dodgson, 1993).The link between lean and organisational learning is made evident in an experiment with Toyota Motor Corporation and their joint venture with General Motors which discovered that lean designs were characterised with rather short cycle times and a higher level of standardisation (Berger, 1997). Therefore, it was apparently easier for 
employees to pick out issues and create improvements and solve problems (Crossan et al., 1999).

Another aspect central to lean which was mentioned in the definition above is that of waste elimination. However, an aspect of lean which is sometimes counter intuitive is that this process of waste elimination lessens the resources often allocated for contingency situations creating a somewhat more fragile system (Crofton and Dale, 1996). This would then rely more heavily on the ability of the employees to react swiftly to deal with malfunctions and smooth out any delays. This concept might be more difficult for cultures which tend to be more risk averse (Browning and Heath, 2009). However, consistency is even more important in this case and employees must abide by a standardised process when undertaking production tasks. The continuous process improvement is however greatly reliant on the pro-activeness of the employees (Cameron, 1994). Workers are given more autonomy in quality checking at the source rather than an entire extra operation for the same task. This is also considered to enhance employee accountability, critical thinking and empowerment which should be facilitated by OC. Studies conducted by Whitfield and Pool (1997), MacDuffie (1997), Kochan et al. (1997) and Vidal (2007) have researched human resource practices which would help to encourage productiveness and voluntary participation from employees for the purpose of lean systems.

Dombrowski et al. (2010) suggests that Lean includes the following important areas; visual management, workplace organisation, $5 \mathrm{~s}$ and process standardisation, continuous improvement, total quality management and total productive maintenance, just in time and production levelling. Rymaszewska (2014) considers it important to organise the components of the list into two schools of thought, one which provides a holistic view of lean emphasising lean as not just tools, but as a philosophy. The other is that Lean should be considered as an addition to current methods employed by manufacturers which is essentially opposite to the holistic view.

\section{Lean assessment}

According to Taj (2005) the majority of companies waste around $70 \%$ to $90 \%$ of their resources. An important notion to realise is that incorrect or unsuitable (LI) which can occur from errors in analysis such as; mistakes in identifying the source of waste, not taking into account the unique organisational situation and environment, utilising the incorrect lean tools (Almomani et al., 2014). Lean assessment is therefore, the first step in the process and it is crucial to get it right in order to avoid a negative impact domino effect. However, no one tool suits all assessment situations. Lean assessment tools can vary in their ease of use, details and metrics provided (Almomani et al., 2014). Ihezie (2009) discovered that the lean assessment tools by Quartman Lee at Strategos Inc. is the most simplest to understand while being able to provide the most detailed information in relation to manufacturing (Taj, 2005; Alsyouf et al., 2011). A similar methodology for lean assessment tool measures several areas including; inventory, employee issues, maintenance, suppliers, safety, production and customers. Scores are then assigned according to the respective leanness of each area and then totalled for a score given to the company as a whole (Alsyouf et al., 2011). The analytic hierarchy process (AHP) helps in solving problem efficiently and precisely and thus is widely utilised. It is particularly 
useful for multi criteria decision making and suitable across numerous sectors such as industry, economy and social among others (Vaidya and Kumar, 2006). It has been suggested that without a clear path for LI devised from correct lean assessment easily results in increased wastage. Furthermore, they discovered that a lean radar score is at times somewhat inaccurate in determining an appropriate path for LI (Almomani et al., 2014). Honda is an excellent example for lean assessment as its main competitor has been Toyota which has been the forerunner in LI (Maxwell et al., 1998). Therefore, Honda also implemented lean philosophies which were well established in its head office in Japan. This same lean philosophy and corporate culture was then transferred to the USA when operations were expanded and they aimed to combine the corporate culture and lean philosophies with the local culture (Maxwell et al., 1998). By utilising benchmarking as a lean assessment tool helped them to quickly catch on and adequately compete with Toyota.

\section{Organisational culture}

According to Davis (1985) culture is defined as, "The pattern of shared beliefs and values that give members of an institution meaning and provide with the rules for behaviour in their organisation," [Sun, (2009), p.138]. Under this theme (OC) is divided into beliefs and daily beliefs. Guiding beliefs provide the context in which the practical beliefs of daily life occur (Sun, 2009). Thirdly, culture is viewed as a strategy. Although Bate (1995) does not agree with a distinction drawn between culture and strategy. He suggests, strategy is in fact a cultural phenomenon (Bate, 1995). This would lead to two inferences; firstly, that any sort of strategy formulation is a cultural activity and secondly all cultural changes would therefore be considered strategic changes (Sun, 2009). Although according to Sun (2009) "Any cultural programme in an organisation is not separate because any change to the cultural program occurs during formal and informal strategic planning processes," [Sun, (2009), p.138]. The fourth theme sees culture as mental programming. This can be seen through Hofstede's definition of culture as, "collective programming of the mind, which distinguishes the members of one category of people from another" [It, (1991), p.5]. Interestingly the understanding of organisational culture and its impact on company performance has been adapting over the decades, (Sørensen and Sorensen, 2002). Peters and Waterman (1982) identified a correlation between a solid organisational culture and successful company and its financial results. However, later on Kotter and Heskett (1992) further added to this by discovering that not only was a strong organisational culture important for company performance, but that it should also be adaptive in order to achieve 'superior performance'. An important aspect to consider when discussing organisational culture is the multidimensional relationship which connects organisational culture and the performance of the company (Kotter and Heskett, 1992). Its impact is far reaching as it involves a number of areas which relate to the organisation's competitive performance (Kotter and Heskett, 1992). Porter (1985) reinforces the notion of achieving the right fit between organisational culture and a specific type of organisational performance. Prior research which embodies the role of organisational cultural influence on performance has been highlighted in numerous researches (Dale and Cooper, 1992; Oackland, 1995; Thomas, 1995; Wilkinson et al., 1998; Stock et al., 2007). According to Ouchi (1981) significant contrasts can be identified between corporate structures of the USA and Japan. Japanese companies tend 
to be characterised with great labour force stability and utilising democratic decision making processes (Mehri, 2006). Furthermore, respect for people is at the cornerstone of their organisational culture and successful LI (Mehri, 2006).

\section{Saudi Arabia: organisational culture and lean}

The Middle East are realising the importance of lean in order to advance operations and practices in the oil and gas industries as value adding and creating high standards in operations (Salem et al., 2016). As most of the non-oil and gas industries are highly dependent on the oil and gas industry in the region; production advancements should naturally trickle down into the other manufacturing industries also. It is this relationship in which Lean thinking enablers can create opportunities for higher operational standards. Although the business environment in Saudi Arabia and the gulf countries is somewhat more difficult in terms of implementing Lean principles compared with industries in other countries (Al-Najem et al., 2012). This is because in KSA and the Middle East countries, most industries are either directly or indirectly linked to the oil and gas industry. The business environment involves a finely woven network of symbiotic relationships and synergies among the industries which can in turn inhibit lean thinking and (LI) (Chiarini, 2012). This is primarily because independent decisions cannot be made without approvals higher up. Furthermore, very little literature on (LI) has been done within the oil and gas sector and especially in the gulf countries. Salem et al. (2015) aimed to asses' aspects pertaining to (LI) in the oil and gas industry. In his research, he discovered that in the case of Qatar, which consists primarily of oil and gas companies, research showed that the majority of companies were not aware of lean (Chiarini, 2012). However, it was identified that a greater awareness of lean existed among the non-oil and gas sector (Salem et al. 2015). It was further highlighted that the awareness of Lean correlated more highly among ISO certified companies as a number of these certifications overlap with lean manufacturing principles (Salem et al., 2015). However, the issue identified is that an understanding of lean among the manufacturing organisations in the Gulf countries is significantly embedded in other management systems such as ISO standards, (ibid). That a failure to understand lean as an isolated philosophy creates barriers. (OC) has been heavily researched which also highlights its importance in organisational performance (Al-Swidi and Mahmood, 2011). Further to this, it has been identified that different regions of the world scubas the Middle East, Eastern Europe, Western Europe and Asian regions all possess uniqueness in terms of (OC) and national culture. Thus, in order to achieve successful Lean systems, each region needs to approach it in a feasible way aligning itself with its own national and corporate cultural mechanisms (AL-Najem et al., 2013).

Not only has literature highlighted a lack of knowledge and difficulties in implementing Lean in the Middle Eastern and Gulf countries, but also and increasing concern of (LI) in SMEs, (Al-Najem, 2014). A reason for the difficulties in implementing lean is a lack of understanding of Toyota's corporate culture and how it facilitated the success of Lean within the organisation (Achanga et al., 2006b). According to Xu et al. (2013) SMEs are a vital part of a nation's economic prosperity and in some Middle Eastern countries SMEs get little attention or support in comparison to the larger oil and gas companies. According to Al-Najem et al. (2013) suggests that research on 
implementing lean in SMEs in Kuwait is non-existent. According Calabrò and Mussolino (2013), SMEs face different challenges in business and in internationalisation due to the nature of numerous informalities which permeate numerous areas of the business such as board members' relationships which are heavily based on trust, informal governance mechanisms and non-economic goals driven by the family in family owned businesses. This informal nature has been attributed to impact on SMEs export intensity (Calabrò and Mussolini, 2013). Calabrò and Mussolini (2013) studied (LI) in SMEs in manufacturing in general suggest, a greater emphasis on in house elements which are less financial in investment are key to the success of (LI) in SMEs. In addition to this, Rose et al. (2013), suggests that SMEs should implement lean gradually starting with aspects which are the easiest to implement and the most cost effective. While the research by Rose et al. (2013) is particularly useful to this study, its focus is on lean best practices for SMEs and (OC) aspects are not addressed. According to MODON (Saudi Industrial Property Authority, 2015) Arabic countries have their own specific attributes and most companies are SMEs with an (OC) that strongly reflects their nature as a 'family' business. MODON (Saudi Industrial Property Authority, 2015) highlights the need for universalising business principles and responsibilities of boards of directors and governance if Arabic SMEs are to be able to internationalise. According to Ahmed et al. (1999), Arab organisations can benefit significantly by implementing quality initiatives to address their weakness and make them more competitive on an international scale. However, there is a real gap in research pertaining to the influence of (OC) in implementing lean among SME's in Arabic countries and Saudi Arabia

\section{Methodology}

Qualitative research is confirmed to be useful for uncovering such insider views (Corbin and Strauss, 1990).The research will be based on qualitative and grounded theory with and an inductive approach. Grounded theory is a research methodology which aims to create a theory from data which has been systematically researched and analysed, (Strauss, 1987). This methodology was founded originally by Glaser and Strauss (1967). According to Golden-Biddle and Locke (2007), grounded theory has been the most vastly utilised qualitative methodology in social science research. Its popularity can be attributed to; firstly, its suitability for developing new theory or new insights form old theory. Secondly, it generates theory which stems from what the research participants consider important. Finally, it is able to expose micro-management processes in complex situations and environments (Locke, 2001). Goulding (1998) suggests grounded theory is particularly useful for making new discoveries thus its usefulness for theory generation. Furthermore, Locke (2001) and Goulding (2005) also consider grounded theory as useful where there is a clear lack of integrated theory in an area of literature. The main feature of this approach is to develop categories which highlight the data and develop the categories to create a framework (Silverman, 2006). Due to the nature of the topic requiring the exploration of culture it is beneficial to utilise qualitative research. An inductive approach enables the researcher to become fully engaged within the research environment thus improving the understanding of the culture being studied, facilitating a more insider's view of the culture (Walker and Myrick, 2006). Furthermore, it is important to note that most methodologies require extensive literature reviews to inform the research and identify the research question as most research methodology is 
conducted with a deductive approach (Dick, 2006). In contrast, grounded theory being inductive ends with a theory as opposed to beginning with a hypothesis and instead is used as a method for reviewing literature (Trochim and Donnelly, 2001). Hence why research questions and hypotheses are made redundant in grounded theory so, literature is generally used as a comparator (Dick, 2006).

Data analysis in qualitative research deals with words and the meanings implied by them (Miles and Huberman, 1994). The analysis of the information gathered is done by discovering categories and their interrelationships. The program utilised for this is NVIVO software for coding. The tool generally employed to study culture consist of; semi structured or in-depth interviews. Interviews are open ended questions gaining in-depth responses about people's experiences, perceptions, opinions and feelings and knowledge (Taylor, 2005). In depth interviews/unstructured interviews are often utilised to help expose culturally based values (Patton, 2014). The key here is, the researcher should not introduce cultural values, but instead using open ended questions and the insider's language, they evoke responses revealing the aspects of everyday life in that cultural setting (Creswell, 2013). It is important for the researcher to be conscious of their own biases and influences in the information gathering process (Patton, 2014). It is important however, for the assisting analysts to also have an understanding of the research setting from an insider's perspective (Sackmann, 1991). For this research semi structures interviews, will also be utilised. The advantage with semi structures interviews is that it ensures certain topics are covered making it more comparable and reliable qualitative information (Patton, 2014).

In order to obtain a better understanding of the nature of (OCs) within SMEs in manufacturing industry this study will focus on three main criteria; firstly, to expose the implied components of culture from an insider's perspective. Secondly, to be mindful of structural aspects of the culture for example sub-cultures (Babbie, 2015). Thirdly, to facilitate comparisons to be made among individuals and research settings (Birkinshaw et al., 2011), the use of this criteria has enabled an issue focused interview style which is founded upon the phenomenological orientation leading to successive comparison, (Birkinshaw et al., 2011). Issue focussed investigation allows for the fulfilment of the above criteria. Due to the nature of culture being omnipresent, this makes it difficult for people to often reflect and describe when asked a question about it directly (Dey, 1999). Therefore, in order to draw this out it often requires a response to stimulus requiring respondents to interpret something, which is naturally done according to their own cultural basis as opposed to that of the researcher (Sackmann, 1991). Furthermore and issue focus investigation is particularly suitable because, by presenting them with a stimulus with a specific context, the respondents then tend to access the same library of knowledge already existing in their minds (Sackmann, 1991). This helps to uncover the framework about a specific issue. This then enables comparisons of the interpretations to uncover individual opinions from cultural beliefs which are common among the group, (Willis et al., 2007). Issue focussed investigation needs to be conducted cleverly to ensure the participants do not realise the issue is under investigation (Sackmann, 1991).

The phenomenological orientation has its focus on the insider's perspective and their beliefs and concepts, ideas of the (OC) and life within it. It places emphasis on the insider's view of what is considered important and relevant within that setting (Goulding, 2005). The researcher will put aside their own assumption so these do not interfere or influence the respondent's answers. The emphasis is to allow the respondents to 
gradually unravel their own experiences. In order for the researcher to avoid making judgments based on their own beliefs, these should firstly be made clear (Annells, 1996). The interview procedure in phenomenological orientation is close in style to an in depth or intense interview. This usually consists of a longer introduction and a period of becoming better acquainted. This also gives the researcher the chance to gently introduce the subject of the discussion (Srubar, 1998). The aspects which are brought up by the respondent are the points which are then delved into with more detail. In doing so, the researcher is better able to explore together with the respondent and identify the cognitive frameworks which come up (Bryant, 2009). This process of an established dialogue also enables the researcher to check they have understood the respondent's point of view correctly. This can be done by the researcher mentally answering the question in their head before the respondent has a chance to check their own accuracy (Goulding, 2005). This type of research requires not only flexibility but a rapport to have been well established between the researcher and the respondent because for in depth issues to come to light the interviewee needs to feel comfortable, safe and that a mutual trust exists (Goulding, 2005).

There are some advantages to employing both an issue focused investigation and a phenomenological orientation. The latter is much unstructured and broad however, the issue focus investigation works to narrow the scope giving more structure to the process. Furthermore, the researcher takes their cue from the respondents as to the most important aspects to be further explored (Sackmann, 1991). The respondents were asking to mention the aspects of Lean they considered most important in their organisation (for example). They were also asked to explain why these were the most important. This enables the researcher to cross compare the responses of the individuals increasing reliability. In the phenomenological phase the researcher ensures all aspects of the factors brought up by the respondents are investigated (Bryant, 2009). Therefore, this particular approach by Sackmann (1991) has been selected for this research. In this case, the questions been asked are issues focussed in accordance with Sackman's (1991) approach: tell me about an example you have seen implementation of lean work well?; tell me about situation of LI has not work well?. Therefore, A combination of issues and phenomenological approach proposed by Sackmann (2006) is being utilised due to its suitability to analysing $(\mathrm{OC})$. In addition to this the grounded theory method of Strauss and Corbin (1994) will be adopted. This is an inquiry mode generally utilised to help solve organisational issues by dealing with those in particular experiencing the problems, (Ibrahim, 2013).

\subsection{Data sampling}

The data sample for the participating companies in this pilot study has been provided in Table 1. The pilot study was conducted in October 2015 with three to four interviews in various companies where lean had been applied but failed. As the study focuses on SMEs for the pilot study, medium sized enterprises were selected in accordance with grounded theory which is the methodological choice for this research. The sampling had been selected based on their experiences. The participants ranged in terms of their position in the organisations. Therefore, the sampling method refers more to events and incidents as opposed to participants (Corbin and Strauss, 1990). 
Table 2 Organisations sample

\begin{tabular}{lccc}
\hline No. of interviews & Industry & Position & Organisation size \\
\hline 4 & Steel & Private & Medium \\
3 & Oil & Private & Medium \\
\hline
\end{tabular}

\subsection{Data collection}

Semi-structured, issue focused interviews have been undertaken for the pilot study. The dates and times were pre-arranged and the interviews took place at their primary place of work. The participants chose the date and time for the interview which would suit them best. According to Kvale (1997), face to face interviews and semi-structure are most effective in providing information rich responses. Thus, adhering to the grounded theory process utilising an issue focused approach (Sackmann, 1991). This was an important aspect which will also be applied in the main study because all levels of employees are considered important in the implementation of lean, (Angelis et al., 2011). Each of the interviews took between 40 and 70 minutes. There was an initial small talk period to get to know each other and break the ice, allowing the interviewee to feel more relaxed. Open ended questions were asked which were issues focused as in accordance with Sackmann (1991). Open ended questions are more likely to prompt the participant to describe their experiences freely. The interviewees were encouraged to share their ideas without any time restrictions. They were also informed that the interviews would be recorded for the purpose of accuracy in the data analysis stage. Grounded theory applies great importance to the perspectives and meanings prescribed to actions and contexts by the research participants. Thus emphasises methodological openness and giving priority to internal validity (Tidjani, 2010). The interviewees were asked to give examples of things that worked well and that did not work well when lean was implemented.

Table 3 Data sample for pilot study

\begin{tabular}{lcccc}
\hline No of interviews & Position & Age & Industry & Interview length \\
\hline 1 & CEO & 52 & Steel & 50 minutes \\
2 & Production engineer & 33 & Steel & 60 minutes \\
3 & Chief engineer & 41 & Steel & 65 minutes \\
4 & Mechanical engineer & 35 & Steel & 45 minutes \\
5 & CEO & 60 & Oil & 55 minutes \\
6 & Production engineer & 39 & Oil & 60 minutes \\
7 & Worker & 30 & Oil & 70 minutes \\
\hline
\end{tabular}

The questions been asked are issues focussed in accordance with Sackman's (1991) approach.

1 Tell me about an example you have seen implementation of lean work well?

2 Tell me about situation of LI has not work well? 


\subsection{Data analysis}

An important feature of grounded theory is the constant comparison method of analysis (Glaser and Strauss, 1998). In this pilot study, only open coding was conducted. Open coding can be defined as, "The analytic processes through which concepts are identified and their properties and dimensions are discovered" [Pal, (2012), p.282]. The pilot study utilised qualitative data software called NVivo which helps researchers analyse large data sets which are common in qualitative research. NVivo helps to enter and code data simultaneously helping to find inter-relationships and identify intricate patterns. NVivo is a package that facilitates analysis of qualitative data. This software permits the coding and subsequent analysis of attributes within a series of documents. NVivo do only present and organise the result from the data. In this level the program utilised for this is NVIVO software for coding section. During this phase of the pilot study, only open coding was conducted. Thus, the researcher role involved segmenting the information into smaller parts and creating discrete codes. Each code represented a set of events or occurrences. In accordance with grounded theory, looking into these issues deeper helps to place the occurrences on a range from one extreme to another (Blaikie, 2009). Data analysis occurs at the same time as the data gathering where the results are continuously compared to new codes until no new codes emerge (Strauss and Corbin, 1998). The data analysis was conducted using line by line coding of the interview transcripts, from which descriptive codes were identified and continuously compared to find similarities and differences.

Figure 1 Grounded theory building process by author

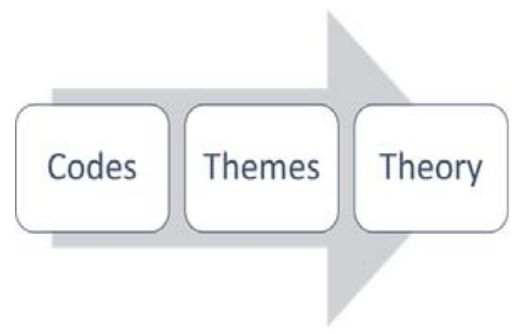

\section{Results and discussion}

\subsection{Findings}

Having conducted the pilot study interviews the codes were developed, these can be seen in Table 3 below. Table 3 provides an overview of organisational culture enablers and inhibitors of (LI). Twenty-nine codes were identified and briefly described. What stands out in Table 4 is the dominance of family effect, many decision makers and teamwork. On the other hand, some codes get less attention such as lack of financial investment in continuous improvement. Teamwork is mentioned by all the participants as an important driving factor for organisational culture. However, aggression on the shop floor hardly affects participants. In general, the findings from the pilot study suggest that family effect and many decision makers can influence the (LI) process. 
Table 4 Pilot study interview aspects

\begin{tabular}{|c|c|c|}
\hline No. & Code & Description \\
\hline 1 & Poor communication & $\begin{array}{l}\text { Failure to convey the correct information to an individual or } \\
\text { group of individuals. This leads to employee misunderstanding } \\
\text { as to what is important and who is responsible for what. }\end{array}$ \\
\hline . & $\begin{array}{l}\text { Procedural activities } \\
\text { not clear }\end{array}$ & $\begin{array}{l}\text { The details of lean implementation activities are not clear. } \\
\text { Leading to confusion regarding the correct steps which need to } \\
\text { be taken. }\end{array}$ \\
\hline 3 & $\begin{array}{l}\text { Health and safety } \\
\text { awareness and } \\
\text { procedures }\end{array}$ & $\begin{array}{l}\text { How the organisation operates its health and safety procedures } \\
\text { in the workplace. A lack of awareness of health and safety } \\
\text { within the workplace leads to poor working conditions. }\end{array}$ \\
\hline 4 & Poor inspection quality & $\begin{array}{l}\text { The quality of inspections is not standardised, leading to delays } \\
\text { in implementing lean. }\end{array}$ \\
\hline 5 & $\begin{array}{l}\text { Lack of professional } \\
\text { training in lean. }\end{array}$ & $\begin{array}{l}\text { Employees are unaware of the lean philosophy, what it aims to } \\
\text { achieve and ultimately how this will be achieved. }\end{array}$ \\
\hline 6 & $\begin{array}{l}\text { A large number of } \\
\text { decision makers }\end{array}$ & $\begin{array}{l}\text { There are numerous employees in middle and senior } \\
\text { management who make decisions based upon their individual } \\
\text { experiences, rather than following a companywide decision } \\
\text { making policy. This leads to confusion and potential errors } \\
\text { within the organisation. }\end{array}$ \\
\hline 7 & Family effect & $\begin{array}{l}\text { Family relationships influence the work process. These can be } \\
\text { positive or negative influences by family members who are } \\
\text { either involved or not involved in the work process of making } \\
\text { organisational decisions. }\end{array}$ \\
\hline 8 & Lack of consultation & $\begin{array}{l}\text { Decision making by senior management is unquestionable, } \\
\text { neither is there a culture of dialogue between management and } \\
\text { employees. This leads to division amongst staff. }\end{array}$ \\
\hline 9 & $\begin{array}{l}\text { Lack of financial } \\
\text { investment in } \\
\text { continuous } \\
\text { improvement }\end{array}$ & $\begin{array}{l}\text { The organisation does not allocate the necessary investment to } \\
\text { continually improve employee productivity. }\end{array}$ \\
\hline 10 & Poor planning & $\begin{array}{l}\text { The organisation regularly wastes a lot of time dealing with } \\
\text { implementation problems which could have been foreseen. }\end{array}$ \\
\hline 11 & Short term focus & $\begin{array}{l}\text { Senior management focuses their efforts on the short term } \\
\text { (weeks/months) as opposed to more long term strategic gaols. }\end{array}$ \\
\hline 12 & No reward systems & $\begin{array}{l}\text { The organisation does not have a rewards based system for } \\
\text { employees or their performance, if these were to exist, } \\
\text { employees would be more productive and motivated. }\end{array}$ \\
\hline 13 & $\begin{array}{l}\text { Promotion non-existent } \\
\text { opportunities }\end{array}$ & $\begin{array}{l}\text { Employees are not given the opportunity to be promoted to } \\
\text { middle/senior management, despite their achievements, } \\
\text { performance or experience. }\end{array}$ \\
\hline 14 & $\begin{array}{l}\text { Poor recruitment } \\
\text { process }\end{array}$ & $\begin{array}{l}\text { Some employees within the organisation are often unskilled } \\
\text { and unexperienced in the work they are doing and thus require } \\
\text { extra training. }\end{array}$ \\
\hline 15 & $\begin{array}{l}\text { Lack of organisational } \\
\text { tools }\end{array}$ & $\begin{array}{l}\text { The organisation does not provide its employees with } \\
\text { organisational tools which can assist in their day to day work, } \\
\text { such as work procedures and handbooks. }\end{array}$ \\
\hline 16 & Request delays & $\begin{array}{l}\text { Due to the high number of management tiers, it takes a long } \\
\text { time before requests can be accepted/rejected. }\end{array}$ \\
\hline
\end{tabular}


Table 4 Pilot study interview aspects (continued)

\begin{tabular}{|c|c|c|}
\hline No. & Code & Description \\
\hline 17 & $\begin{array}{l}\text { Lack of knowledge } \\
\text { within senior } \\
\text { management }\end{array}$ & $\begin{array}{l}\text { On a strategic level the senior management team within the } \\
\text { organisation are aware of the need for lean, and the advantages } \\
\text { it can bring. However, they do not understand the lean } \\
\text { philosophy, nor are they willing to learn. }\end{array}$ \\
\hline 18 & $\begin{array}{l}\text { Multi-tasking } \\
\text { (negative) }\end{array}$ & $\begin{array}{l}\text { Employees within the organisation are given many roles and } \\
\text { tasks, which causes them confusion and does not allow them to } \\
\text { finish their tasks properly. }\end{array}$ \\
\hline 19 & $\begin{array}{l}\text { No } \\
\text { feedback/evaluation } \\
\text { system }\end{array}$ & $\begin{array}{l}\text { Feedback or evaluation systems are non-existent. If these were } \\
\text { available, it would enable management to understand problems } \\
\text { raised by employees. Employees are unable to understand the } \\
\text { impact of decisions made by senior management. }\end{array}$ \\
\hline 20 & $\begin{array}{l}\text { Unclear prioritisation } \\
\text { of tasks }\end{array}$ & $\begin{array}{l}\text { The sequence of tasks which needs to be completed are unclear, } \\
\text { especially because the employees are regularly given different } \\
\text { tasks to complete, as the organisational priorities are } \\
\text { changeable. }\end{array}$ \\
\hline 21 & $\begin{array}{l}\text { No performance } \\
\text { indicators }\end{array}$ & $\begin{array}{l}\text { There is no system of recording employee performance, } \\
\text { therefore the organisation is unable to understand employee } \\
\text { productivity. }\end{array}$ \\
\hline 22 & $\begin{array}{l}\text { No contingency } \\
\text { planning }\end{array}$ & $\begin{array}{l}\text { The organisation does not have a contingency plan which could } \\
\text { guide them in case of an emergency, and thus resume operations } \\
\text { as per norm. }\end{array}$ \\
\hline 23 & No teamwork & $\begin{array}{l}\text { Cross-departmental communication and teamwork needs to } \\
\text { improve greatly. Building awareness of teamwork can only } \\
\text { improve performance. }\end{array}$ \\
\hline 24 & No receptivity & $\begin{array}{l}\text { Senior management are unreceptive to ideas/improvements } \\
\text { which have been put forward by junior employees. }\end{array}$ \\
\hline 25 & No external support & $\begin{array}{l}\text { The organisation does not seek professional guidance/advice } \\
\text { from external sources, instead relies on its employees. }\end{array}$ \\
\hline 26 & Job security & $\begin{array}{l}\text { There is no guarantee of job security, despite efforts being made } \\
\text { by employees. }\end{array}$ \\
\hline 27 & Geographic movement & $\begin{array}{l}\text { Difficulty for employees to move around within the } \\
\text { confinements of their workplace. }\end{array}$ \\
\hline 28 & Openness & $\begin{array}{l}\text { Employees do not feel safe to share their inner thoughts or } \\
\text { feelings with senior management as they fear they will receive } \\
\text { negative feedback. }\end{array}$ \\
\hline 29 & $\begin{array}{l}\text { Aggression towards } \\
\text { the shop floor }\end{array}$ & $\begin{array}{l}\text { Due to the hierarchical nature of the organisation, senior } \\
\text { management are sometimes aggressive in giving } \\
\text { directions/instructions to employees in lower ranks. }\end{array}$ \\
\hline
\end{tabular}


Table 5 Interviews codes repetition

\begin{tabular}{|c|c|c|c|c|c|c|c|c|c|}
\hline No. & Participants codes & 1 & 2 & 3 & 4 & 5 & 6 & 7 & Total \\
\hline 1 & Poor communication & 1 & & & & 2 & 1 & 3 & 7 \\
\hline 2 & Procedural activities not clear & & & & & & & 2 & 2 \\
\hline 3 & Low of health and safety awareness & & & & & 1 & 1 & 1 & 3 \\
\hline 4 & Poor inspection quality & & & & 1 & 1 & 1 & 1 & 4 \\
\hline 5 & Lack of professional training in lean & & & 1 & 1 & 1 & 0 & 2 & 5 \\
\hline 6 & A large number of decision makers & & & 1 & 1 & 1 & 2 & 3 & 8 \\
\hline 7 & Family effect & & & 2 & 3 & 3 & 3 & 4 & 15 \\
\hline 8 & Lack of consultation & & & & 1 & 1 & 1 & 1 & 4 \\
\hline 9 & $\begin{array}{l}\text { Lack of financial investment in continuous } \\
\text { improvement }\end{array}$ & & & & 1 & & 1 & & 2 \\
\hline 10 & poor planning & & & & & 1 & & 1 & 2 \\
\hline 11 & Short term focus & & & 1 & 1 & 1 & 1 & 1 & 5 \\
\hline 12 & No reward systems & & & 2 & 1 & 1 & & 1 & 5 \\
\hline 13 & Promotion non-existent opportunities & 1 & 1 & 1 & & & & & 3 \\
\hline 14 & Poor recruitment process & 1 & 1 & 1 & & & & & 3 \\
\hline 15 & Lack of organisation tools & & & & & 1 & & 1 & 2 \\
\hline 16 & Request delays & & & & & 2 & 1 & 1 & 4 \\
\hline 17 & Lack of knowledge within top management & & & 2 & 1 & 1 & 1 & & 5 \\
\hline 18 & Multi-tasking & & & & & & 1 & 3 & 4 \\
\hline 19 & No feedback system & & & & 1 & & 2 & 1 & 4 \\
\hline 20 & Prioritisation of tasks unclear & & & & & & 1 & 1 & 2 \\
\hline 21 & No performance indicators & & & & & 1 & 1 & & 2 \\
\hline 22 & No contingency planning & & & 1 & & & 1 & 1 & 3 \\
\hline 23 & No teamwork & & & 1 & 1 & 1 & 1 & 1 & 5 \\
\hline 24 & No receptivity & & & & & & & 4 & 4 \\
\hline 25 & No external support & 1 & & 2 & 1 & 1 & 1 & & 6 \\
\hline 26 & Job security & & & & & 1 & 1 & 1 & 3 \\
\hline 27 & Geographic movement & & & & & & 1 & 1 & 2 \\
\hline 28 & Openness & & & & & 1 & 1 & 2 & 4 \\
\hline 29 & Aggression to the shop floor & & & & & & & 2 & 2 \\
\hline
\end{tabular}




\subsection{Constant comparison}

Having explored all the codes from the interviews conducted, the next step was to compare all the codes and information to the literature review. The aim of this is to identify existing researched information and new information which has not been identified before (Charmaz, 1995).There is a large volume of published studies describing the role of lack of consultation, external support from consultation and no professional training (Womack and Jones, 1996; Allen and Meyer, 1997; Shah, 2003; Womack and Jones, 2003; Achanga et al., 2006; Shah and Ward, 2007; Angelis et al., 2011; Panizzolo et al., 2012). The existing literature review on (LI) barriers is extensive and focuses particularly on poor communication, teamwork and poor planning (Womack et al., 1990; Crofton and Dale, 1996; Womack and Jones, 1996; Womack and Jones, 2003; Mann, 2009; Angelis et al., 2011; Hu et al., 2015). Over the past decade, most research in LI has emphasised the use of safety and inspection quality (Munene, 1995; Crofton and Dale, 1996; Dixon, 1999). It has been noted that some of the codes get less attention such as no performance indicators and an aggressiveness towards shop floor employees, also affected the process of LI (Swank, 2003; Mann, 2009; Angelis et al., 2011; Al-Najem et al., 2012; Hu et al., 2015). While comparing each code to the literature review in relation to (LI) for SMEs and organisational culture, it became apparent that two codes were unique in the pilot study interviews. These two aspects did not appear in the literature review. These two codes are; the issue of many decision makers in the company and the family effect. The code for 'many decision makers' was taken from the following statement in the interview:

\footnotetext{
"Many of the decisions made at the same time from several different departments. For example, the production manager, my supervisor and the stock manager, as well as some of the orders were contradictory at the same time. Also, another example of this is, the production manager asks us to complete a particular implementation of the task and after a little while my supervisor asks us to perform another task while we didn't finish the previous tasks ... and that's it ... unbelievable."
}

The other code, 'the family effect' was:

"One of the family member, involved himself throughout the implementation process and instructed us, while he is not member of the company ... I cannot tell you who is [laughing]."

Calabrò and Mussolino (2013) characteristic of many SMEs, there tends to be a strong existence of trust amongst board members which results in a number of informal social processes. Moreover, Table 4 shows how these two factors influence the organisation and the number of times it is mentioned. This is believed to influence the level of internationalisation and governance of the company (Ramaswamy et al., 2000). It has been identified that SMEs face unique governance issues as they tend to balance a combination of formal and informal aspects which include non-economic goals pursued by the family as in the case of family businesses (Calabrò and Mussolino, 2013). Thus, the informality which appears to be a common characteristic of SMEs, impacts on organisational practices and processes. Thus, in many ways the pilot study has uncovered a couple of organisational cultural aspects common SMEs which is incongruent to enabling lean. 


\section{Conclusions}

This pilot study begins with the first stages of the grounded theory method by Strauss and Corbin (1998) with open coding. The following coding stages of grounded theory are followed through in the main study. The main purpose of the pilot study was to uncover the areas which enable and inhibit (LI) that has not yet been identified in prior research by use of the literature review. In order to do this, a sample of two organisations were selected each being in the oil and steel industry and from medium sized organisations. Among these a total of seven interviews were conducted with employees of all levels from CEO's to factory workers because all employees are considered equally important to the implementation of lean. Thus, it is important this is also reflected in the pilot study. The interviews were conducted with an issue focussed approach in accordance with Sackmann's (1991). The interviews were analysed with NVivo qualitative data analysis software in order to help identify complex patterns within the interview results. The interviews were also analysed by reading line by line and creating codes from each of the comments made. Many of the aspects brought up in the interviews correlated with the data from the literature review (Charmaz, 1995). However, there were two codes which had not been evidenced in prior researches and were not identified in the literature review. These include; 'many decision makers' and the 'family effect'. Moreover, the family effect is also unsurprising in the case of SMEs as lines of formalities regarding the influence and involvement of family members become blurred in family companies, (Ramaswamy et al., 2000) Furthermore, when a frequency table was created it was discovered that these two aspects which had not been previously researched were raised with higher frequency than any of the other aspects that correlated with the findings in the literature review. These aspects are also especially relevant and characteristic of SME's (Calabrò and Mussolino, 2013). Thus, this highlights the main research which suggests to explore further in order to develop a framework for creating an organisational culture that encourages the success of (LI) amongst SMEs in Saudi Arabia.

\section{Acknowledgements}

This study is a part of a developing framework to facilitate (LI) within SMEs and manufacturing companies by leveraging aspects of organizational culture.

\section{References}

Achanga, P., Shehab, E., Roy, R. and Nelder, G. (2006) 'Critical success factors for lean implementation within SMEs', in Saad, S. (Ed.): Journal of Manufacturing Technology Management, Vol. 17, No. 4, pp.460-471, DOI: 10.1108/17410380610662889.

Adler, P. and Cole, R. (1995) 'Designed for learning: a tale of two auto plants', in Sloan (Ed.): Management Review, Vol. 34, No. 3, p.85.

Ahmed, P.K., Loh, A.Y.E. and Zairi, M. (1999) 'Cultures for continuous improvement and learning', Total Quality Management, Vol. 10, Nos. 4-5, pp.426-434, doi: 10.1080/ 0954412997361.

Allen, N. and Meyer, J. (1997) Commitment in the Workplace: Theory, Research and Application, Thousand Oaks. 
Allen, N.J. and Meyer, J.P. (1993) 'Organizational commitment: evidence of career stage effects?', Journal of Business Research, Vol. 26, No. 1, pp.49-61, DOI: 10.1016/0148-2963(93)90042N.

Almomani, M.A., Abdelhadi, A., Mumani, A., Momani, A. and Aladeemy, M. (2014) 'A proposed integrated model of lean assessment and analytical hierarchy process for a dynamic road map of lean implementation', International Journal of Advanced Manufacturing Technology, Vol. 72, Nos. 1-4, pp.161-172, DOI: 10.1007/s00170-014-5648-3.

Al-Najem, M., Dhakal, H. and Bennett, N. (2012) 'The role of culture and leadership in lean transformation: a review and assessment mode', International Journal of Lean Thinking, Vol. 3, No. 1, pp.119-138.

Alshahrani, S.A. and Alsadiq, A.J. (2014) 'Economic growth and government spending in Saudi Arabia: an empirical investigation', IMF Working Papers, Vol. 14, No. 3, p.1, DOI: $10.5089 / 9781484348796.001$.

Alstrup, L. (2000) 'Coaching continuous improvement in small enterprises', Integrated Manufacturing Systems, Vol. 11, No. 3, pp.165-170, DOI: 10.1108/09576060010320371.

Al-Swidi, A. and Mahmood, R. (2011) 'How does organizational culture shape the relationship between entrepreneurial orientation and the organizational performance of banks?', European Journal of Social Sciences, Vol. 20, No. 1, pp.28-46.

Alsyouf, I., Aomar, R., Al-Hamed, H. and Qiu, X. (2011) 'A framework for assessing the cost effectiveness of lean tools', European J. of Industrial Engineering, Vol. 5, No. 2, p.170, DOI: 10.1504/EJIE.2011.039871.

Angelis, J., Conti, R., Cooper, C. and Gill, C. (2011) 'Building a high-commitment lean culture', Journal of Manufacturing Technology Management, Vol. 22, No. 5, pp.569-586, DOI: $10.1108 / 17410381111134446$.

Annells, M. (1996) 'Grounded theory method: philosophical perspectives, paradigm of inquiry, and postmodernism', Qualitative Health Research, Vol. 6, No. 3, pp.379-393, DOI: $10.1177 / 104973239600600306$.

Babbie, E. (2015) The Practice of Social Research, Nelson Education, London.

Bate, P. (1995) Strategies for Cultural Change, The Service Industries Journal, ButterworthHeinemann, Oxford.

Berger, A. (1997) 'Continuous improvement and kaizen: standardization and organizational designs', Integrated Manufacturing Systems, MCB UP Ltd., Vol. 8, No. 2, pp.110-117, DOI: $10.1108 / 09576069710165792$.

Bhamu, J. and Singh Sangwan, K. (2014) 'Lean manufacturing: literature review and research issues', International Journal of Operations \& Production Management, Vol. 34, No. 7, pp.876-940, DOI: 10.1108/IJOPM-08-2012-0315.

Bhasin, S. (2012) 'Prominent obstacles to lean', International Journal of Productivity and Performance Management, Vol. 61, No. 4, pp.403-425, doi: 10.1108/17410401211212661, Emerald Group Publishing Limited.

Birkinshaw, J., Brannen, M.Y. and Tung, R.L. (2011) 'From a distance and generalizable to up close and grounded: reclaiming a place for qualitative methods in international business research', Journal of International Business Studies, pp.573-581, doi: 10.1057/jibs.2011.19.

Blaikie, N. (2009) Designing Social Research, 2nd ed., Polity Press, Cambridge.

Browning, T.R. and Heath, R.D. (2009) 'Reconceptualizing the effects of lean on production costs with evidence from the F-22 program', Journal of Operations Management, Vol. 27, No. 1, pp.23-44, DOI: 10.1016/j.jom.2008.03.009.

Bryant, A. (2009) 'Grounded theory and pragmatism: the curious case of anselm strauss', Forum Qualitative Sozialforschung, Vol. 10, No. 3.

Calabrò, A. and Mussolino, D. (2013) 'How do boards of directors contribute to family SME export intensity? The role of formal and informal governance mechanisms', Journal of Management \& Governance, Vol. 17, No. 2, pp.363-403, DOI: 10.1007/s10997-011-9180-7. 
Cameron, K.S. (1994) 'Strategies for successful organizational downsizing', Human Resource Management, Vol. 33, No. 2, pp.189-211, DOI: 10.1002/hrm.3930330204.

Charmaz, K. (1995) 'Grounded theory', in Smith, J., Harre, R. and Van Langenhove, L. (Eds.): Rethinking Methods in Psychology, pp.27-49, Sage, London.

Chase, N. (1999) 'Lose the waste: get lean!', Quality, Vol. 38, No. 3, pp.34-39.

Chay, T., Xu, Y., Tiwari, A. and Chay, F. (2015) 'Towards lean transformation: the analysis of lean implementation frameworks', Journal of Manufacturing Technology Management, Vol. 26, No. 7, pp.1031-1052, doi: 10.1108/JMTM-10-2013-0143.

Chiarini, A. (2012) 'Lean production: mistakes and limitations of accounting systems inside the SME sector', in Bates, K. (Ed.): Journal of Manufacturing Technology Management, Vol. 23, No. 5, pp.681-700, doi: 10.1108/17410381211234462.

Corbett, S. (2007) 'Beyond manufacturing: the evolution of lean production', McKinsey Quarterly, Vol. 3, No. 3, pp.94-96.

Corbin, J. and Strauss, A. (1990) Basics of Qualitative Research: Grounded Theory Procedures and Techniques, Basics of Qualitative Research, Sage.

Creswell, J. (2013) Research Design: Qualitative, Quantitative, and Mixed Methods Approaches, SAGE Publications, London.

Crofton, C.G. and Dale, B.G. (1996) 'The difficulties encountered in the introduction of total quality management: a case study examination', Quality Engineering, Taylor \& Francis Group, Vol. 8, No. 3, pp.433-439, DOI: 10.1080/08982119608904645.

Crossan, M.M., Lane, H.W. and White, R.E. (1999) 'An organizational learning framework: from intuition to institution', Academy of Management Review, Vol. 24, No. 3, pp.522-537, DOI: 10.5465/AMR.1999.2202135.

Dale, B. and Cooper, C. (1992) Total Quality and Human Resources: An Executive Guide, Blackwell, London.

Davis, T. (1985) 'Managing culture at the bottom', Gaining Control of the Corporate Culture, Vol. 2, No. 3, pp.163-183.

Dey, I. (1999) Grounding Grounded Theory: Guidelines for Qualitative Inquiry, Academic Press, London.

Dick, B. (2006) Grounded Theory: A Thumbnail Sketch, Vol. 25, pp.1-19, doi: 10.1109/DATE. 2008.4484729.

Dixon, N.M. (1999) The Organizational Learning Cycle: How We Can Learn Collectively, Gower Publishing Ltd., London [online] https://books.google.com/books?hl=en\&lr=\&id= gTn1rJFSOm0C\&pgis=1 (accessed October 2016).

Dodgson, M. (1993) 'Organizational learning: a review of some literatures', Organization Studies, Vol. 14, No. 3, pp.375-394 [online] http://oss.sagepub.com/content/14/3/375.short (accessed 26 April 2016).

Dombrowski, U., Crespo, I. and Zahn, T. (2010) 'Adaptive configuration of a lean production system in small and medium-sized enterprises', Production Engineering, Vol. 4, No. 4, pp.341-348, DOI: 10.1007/s11740-010-0250-5.

European Commission (2011) Guide to EU Definition of SME [online] http://ec.europa.eu/ growth/smes/business-friendly-environment/sme-definition/index_en.htm (accessed 15 May 2015).

Glaser, B. and Strauss, A. (1967) 'The discovery of grounded theory', Strategies for Qualitative Research, Weidenfeld, London.

Glaser, B. and Strauss, A. (1998) 'Grounded theory', Strategien Qualitativer Forschung, Bern, Vol. 19, No. 4, pp.0260-0260, doi: 10.1024/1012-5302.19.4.260a.

Golden-Biddle, K. and Locke, K. (2007) Composing Qualitative Research, 2nd ed., Sage [online] $\mathrm{https}$ ://books.google.co.uk/books?hl=en\&lr=\&id=2nn0ZJ8ouB8C\&oi=fnd\&pg=PR7\&dq=Co mposing + qualitative + research\&ots $=2 \mathrm{aGLfO} h \mathrm{hEd} \&$ sig $=\mathrm{iIP} 3 \mathrm{SOEGkD}-\mathrm{ewVpl7jxtVjCBLto}$ (accessed January 2015). 
Goulding, C. (1998) 'Grounded theory: the missing methodology on the interpretivist agenda', Qualitative Market Research: An International Journal, Vol. 1, No. 1, pp.50-57, DOI: $10.1108 / 13522759810197587$.

Goulding, C. (2005) 'Grounded theory, ethnography and phenomenology', Lee, N. (Ed.): European Journal of Marketing, Vol. 39, Nos. 3/4, pp.294-308, DOI: 10.1108/03090560510581782.

Graham-jones, J. and Muhareb, T.M. (2015) Using Lean Six-Sigma in the Improvement of Service Quality at Aviation Industry: Case Study at the Departure Area in KKIA, March.

Hopp, W.J. and Spearman, M.L. (2004) 'To pull or not to pull: what is the question?', Manufacturing and Service Operations Management, Vol. 6, No. 2, pp.133-148, DOI: $10.1287 / \mathrm{msom} .1030 .0028$.

Hu, Q., Mason, R., Williams, S.J. and Found, P. (2015) 'Lean implementation within SMEs: a literature review', Journal of Manufacturing Technology Management, Vol. 26, No. 7, pp.980-1012, DOI: 10.1108/JMTM-02-2014-0013.

Hungler, B., Beck, C. and Polit, D. (2001) Essentials of Nursing Research: Methods, Appraisals and Utilization, 5th ed., Lippincott Williams and Wilkins, Philadelphia.

Ibrahim, U. (2013) Investigating the Effects of Corporate Governance of Banks in Nigeria: A Grounded Theory Approach, Plymouth University.

Ihezie, D.H.S. (2009) Applying Lean Assessment Tools at a Maryland Manufacturing Company, American Society for Engineering Education (ASEE).

It, C. (1991) 'HOFSTEDE: cultures and organizations - software of the mind', Development, pp.1-29, McGaw-Hill, London.

Karim, A. and Arif-Uz-Zaman, K. (2013) 'A methodology for effective implementation of lean strategies and its performance evaluation in manufacturing organizations', Business Process Management Journal, Vol. 19, No. 1, pp.169-196, DOI: 10.1108/14637151311294912.

Karim, M.A., Aljuhani, M., Duplock, R. and Yarlagadda, P. (2011) 'Implementation of lean manufacturing in saudi manufacturing organisations: an empirical study', Advanced Materials Research, Vol. 339, pp.250-253, DOI: 10.4028/www.scientific.net/AMR.339.250.

Kochan, T., Lansbury, R. and Macduffie, J. (1997) After Lean Production: Evolving Employment Practices in the World Auto Industry, Cornell University Press, New York.

Kotter, J.P. and Heskett, J. (1992) Corporate Culture and Performance, The Free Press, New York.

Kvale, S. (1997) 'InterViews: an introduction to qualitative research interviewing', Evaluation and Program Planning, Vol. 3, No. 20, pp.287-288.

Lewis, M.A. (2000) 'Lean production and sustainable competitive advantage', International Journal of Operations \& Production Management, Vol. 20, No. 8, pp.959-978, doi: 10.1108/ 01443570010332971.

Lin, Z. and Hui, C. (1999) 'Should lean replace mass organization systems? A comparative examination from a management coordination perspective', Journal of International Business Studies, Vol. 30, No. 1, pp.45-79, doi: 10.1057/palgrave.jibs.8490060.

Locke, K. (2001) Grounded Theory in Management Research, Sage [online] https://books.google.co.uk/books?hl=en\&lr=\&id=OcDWB-rWvWUC\&oi=fnd\&pg=PR7\&dq= Grounded+Theory + in + Management + Research\&ots $=X p N K m Q$ _-8n\&sig $=$ S 7FYKQRplq1SRwd_aSjzm5c3VQ (accessed November 2015).

MacDuffie, J.P. and Helper, S. (1997) 'Creating lean suppliers: diffusing lean production through the supply chain', California Management Review, Vol. 39, No. 4, pp.118-151.

Mann, D. (2009) 'The missing link: lean leadership', Frontiers of Health Services Management, Vol. 26, No. 2, p.15.

Maxwell, J., Briscoe, F., Schenk, B. and Rothenberg, S. (1998) 'Case study: Honda of America Manufacturing, Inc.: can lean production practices increase environmental performance?', Environmental Quality Management, Vol. 8, No. 1, pp.53-61, DOI: 10.1002/ tqem.3310080107. 
Mehri, D. (2006) 'The darker side of lean: an insider's perspective on the realities of the Toyota production system', Academy of Management Perspectives, Vol. 20, No. 2, pp.21-42, DOI: 10.5465/AMP.2006.20591003.

Miles, M. and Huberman, A. (1994) Qualitative Data Analysis: An Expanded Sourcebook, Sage, London.

Munene, J. (1995) ' Not-on-seat': an investigation of some correlates of organisational citizenship behaviour in Nigeria', Applied Psychology, Vol. 44, No. 2, pp.111-122, DOI: 10.1111/j.14640597.1995.tb01069.x.

Oackland, J. (1995) Total Quality Management. The Route to Improving Performance, 2nd ed., Butterworth-Heinemann, Oxford.

Oliver, N. and Hunter, G. (1998) The Financial Impact of 'Japanese' Manufacturing Methods, Manufacturing in Transition, pp.81-91, Routlege \& Kegan Paul, London.

Ouchi, W. (1981) 'Theory Z: how American business can meet the Japanese challenge', Business Horizons, Vol. 24, No. 6, pp.82-83, doi: 10.1016/0007-6813(81)90031-8.

Pal, S. (2012) 'A qualitative inquiry into work-family conflict among Indian doctors and nurses', Work, Vol. 42, No. 2, pp.279-288.

Panizzolo, R., Garengo, P., Sharma, M.K. and Gore, A. (2012) 'Lean manufacturing in developing countries: evidence from Indian SMEs', Production Planning \& Control, Vol. 23, Nos. 10-11, pp.769-788, DOI: 10.1080/09537287.2011.642155.

Patton, M.Q. (2014) Qualitative Research \& Evaluation Methods: Integrating Theory and Practice, SAGE Publications [online] https://books.google.com/books?id=-CM9BQAAQBAJ\&pgis=1 (accessed October 2015).

Pay, R. (2008) 'Everybody's jumping on the lean bandwagon, but many are being taken for a ride', Industry Week, No. 503, pp.21-23.

Peters, T., Waterman, R. and Jones, I. (1982) In Search of Excellence: Lessons from America's Best-Run Companies, 1st ed., Harper, New York.

Pingyu, Y. and $\mathrm{Yu}, \mathrm{Y}$. (2010) 'A review on lean manufacturing practices in small and medium enterprises', International Journal of Innovation, Management and Technology, Vol. 1, No. 2 , pp.220-225.

Pooyan, B., Napsiah, I. and Zulkiflle, L. (2014) 'Review of lean adoption within small and medium sized enterprises', Advanced Materials Research. Trans Tech Publications, Vol. 903, pp.414-418, DOI: 10.4028/www.scientific.net/AMR.903.414.

Porter, M. (1985) Competitive Advantage: Creating and Sustaining Superior Performance, Free Press, New York; Export edition, London.

Ramaswamy, K., Veliyath, R. and Gomes, L. (2000) 'A study of the determinants of CEO compensation in India', MIR: Management International Review, Vol. 40, No. 2, pp.167-191.

Rose, M.A.N.M., Deros, B.M. and Rahman, M.N.A. (2013) 'Lean manufacturing perceptions and actual practice among Malaysian $\{\mathrm{SME}\}$ 's in automotive industry', International Journal of Automotive and Mechanical Engineering, Universiti Malaysia Pahang Publishing, Vol. 7, pp.820-829, doi: 10.15282/ijame.7.2012.2.0067.

Rymaszewska, A.D. (2014) 'The challenges of lean manufacturing implementation in SMEs', Benchmarking: An International Journal, Vol. 21, No. 6, pp.987-1002, DOI: 10.1108/BIJ-102012-0065.

Sackmann, S. (1991) 'Uncovering culture in organizations', The Journal of Applied Behavioral Science, Vol. 27, No. 3, pp.295-317.

Sackmann, S. (1991) 'Uncovering culture in organizations', The Journal of Applied Behavioral Science, Vol. 27, No. 3, pp.295-317, doi: 10.1177/0021886391273005.

Sackmann, S. (2006) Success Factor: Corporate Culture: Developing A Corporate Culture For High Performance and Long Term Competitiveness: six best practices, Verlag Bertelsmann Stiftung, Gütersloh. 
Salem, O., Solomon, J., Genaidy, A. and Minkarah, I. (2006) 'Lean construction: from theory to implementation', Journal of Management in Engineering, Vol. 22, No. 4, pp.168-175, DOI: 10.1061/(ASCE)0742-597X(2006)22:4(168).

Saudi Industrial Property Authority (2015) Saudi Industrial Property Authority, MODON [online] http://www.modon.gov.sa/en/Pages/default.aspx (accessed 20 August 2015).

Saudi Industrial Property Authority (2015) Saudi Industrial Property Authority, MODON [online] http://www.modon.gov.sa/en/Pages/default.aspx (accessed 20 August 2015).

Schouteten, R. and Benders, J. (2004) 'Lean production assessed by Karasek's job demand-job control model', Economic and Industrial Democracy, Vol. 25, No. 3, pp.347-373, DOI: $10.1177 / 0143831 X 04044831$.

Shah, R. (2003) 'Lean manufacturing: context, practice bundles, and performance', Journal of Operations Management, Vol. 21, No. 2, pp.129-149, DOI: 10.1016/S0272-6963(02)00108-0.

Shah, R. and Ward, P.T. (2007) 'Defining and developing measures of lean production', Journal of Operations Management, Vol. 25, No. 4, pp.785-805, DOI: 10.1016/j.jom.2007.01.019.

Silverman, D. (2006) Interpreting Qualitative Data: Methods for Analyzing Talk, Text and Interaction, 3rd ed., Sage, Los Angeles [online] https://books.google.co.uk/books? $\mathrm{hl}=\mathrm{en} \& \mathrm{lr}=\& \mathrm{id}=$ uooz4p $82 \mathrm{sDgC} \& \mathrm{oi}=$ fnd $\& \mathrm{pg}=\mathrm{PP} 1 \& \mathrm{dq}=$ Interpreting + qualitative + data.+ Method $\mathrm{s}+$ for+analyzing + talk, +text+and+interaction\&ots $=u$ PWFZmufGR\&sig=nMLeyQ1rm6KpQQ-QCIsoTgYH6U (accessed January 2015).

Sørensen, J.B. and Sorensen, J.B. (2002) 'The strength of corporate culture and the reliability of firm performance', Administrative Science Quarterly, Vol. 47, No. 1, p.70, DOI: $10.2307 / 3094891$.

Srubar, I. (1998) 'Phenomenological analysis and its contemporary significance', Human Studies, Vol. 21, No. 2, pp.121-139, DOI: 10.1023/A:1005355921478.

Stock, G.N., McFadden, K.L. and Gowen, C.R. (2007) 'Organizational culture, critical success factors, and the reduction of hospital errors', International Journal of Production Economics, Vol. 106, No. 2, pp.368-392, DOI: 10.1016/j.ijpe.2006.07.005.

Stone, K.B. (2012) 'Four decades of lean: a systematic literature review', International Journal of Lean Six Sigma, Vol. 3, No. 2, pp.112-132, doi: 10.1108/20401461211243702.

Strauss, A. (1987) Qualitative Analysis for Social Scientists, Cambridge University Press [online] https://books.google.co.uk/books?hl=en\&lr=\&id=y16ww5ZsJ0AC\&oi=fnd\&pg=PA109\&dq= Qualitative+analysis+for+social+scientists\&ots $=\mathrm{gV} 8 \mathrm{wNShaiS} \&$ sig=t65cOdLOiuvOImCBO 8 7_UKCYBWI (accessed 16 April 2016).

Strauss, A. and Corbin, J. (1994) 'Grounded theory methodology', Handbook of Qualitative Research, pp.273-285.

Strauss, A. and Corbin, J. (1998) Basics of Qualitative Research: Procedures and Techniques for Developing Grounded Theory, Sage.

Sun, S. (2009) 'Organizational culture and its themes', International Journal of Business and Management, Vol. 3, No. 12, doi: 10.5539/ijbm.v3n12p137.

Swank, C. (2003) 'The lean service machine', Harvard Business Review, Vol. 81, No. 10, pp. $123-130$.

Taj, S. (2005) 'Applying lean assessment tools in Chinese hi - tech industries', Management Decision, 43(4), pp. 628-643. doi: 10.1108/00251740510593602.

Taylor, G.R. (2005) Integrating Quantitative and Qualitative Methods in Research, University Press of America.

Thomas, B. (1995) The human dimension of quality. New York: McGraw-Hill.

Tidjani, B. (2010) 'Senegalese Entrepreneurs in the USA and Managerial Decision making: A pilot study', Africa Development. CODESRIA, 32(2). doi: 10.4314/ad.v32i2.57174.

Trochim, W. and Donnelly, J. (2001) 'Research methods knowledge base'.

Vaidya, O. S. and Kumar, S. (2006) 'Analytic hierarchy process: An overview of applications', European Journal of Operational Research, 169(1), pp. 1-29. doi: 10.1016/j.ejor.2004.04.028. 
Vidal, M. (2007) 'Manufacturing empowerment?'Employee involvement'in the labour process after Fordism', Socio-economic review, 5(2), pp. 197-232. Available at: http://ser.oxfordjournals.org/content/5/2/197.short.

Walker, D. and Myrick, F. (2006) 'Grounded theory: an exploration of process and procedure', Qualitative Health Research, Vol. 16, No. 4, pp.547-559, DOI: 10.1177/1049732305285972.

Whitfield, K. and Poole, M. (1997) 'Organizing employment for high performance: theories, evidence and policy', Organization Studies, Vol. 18, No. 5, p.745 [online] http://oss.sagepub.com/content/18/5/745.short (accessed 26 April 2016).

Wilkinson, A., Redman, T., Snape, E. and Marchington, M. (1998) Managing with Total Quality Management, Macmillan, London.

Willis, J., Jost, M. and Nilakanta, R. (2007) Foundations of Qualitative Research: Interpretive and Critical Approaches, Sage, SAGE Publications.

Womack, J. and Jones, D.T. (2003) Lean Thinking: Banish Waste and Create Wealth in your Corporation, 2nd ed., Simon and Schuster, New York.

Womack, J., Jones, D. and Roos, D. (1990) Machine that Changed the World, Simon and Schuster [online] https://books.google.co.uk/books?hl=en\&lr=\&id= n5qRfaNv9AC\&oi=fnd\&pg=PR7 $\& \mathrm{dq}=$ The + Machine + that + Changed + the + World \&ots $=$ cr $7 \mathrm{~kJ} 2 \mathrm{FMy} 2 \&$ sig $=$ OOmvICCN $8 \mathrm{XJ} 3 \mathrm{sU}$ u3oQvVCbCYWkk (accessed January 2015).

Womack, J.P. and Jones, D.T. (1996) Lean Thinking: Banish Waste And Create Wealth In Your Corporation, Simon and Schuster, New York [online] https://books.google.com/ books?id=QZrZAAAAQBAJ\&pgis=1 (accessed May 2016).

Xu, L.X.X., Wang, F.Y., Lim, R., Toh, M.H. and Valliappan, R. (2013) 'Lean implementation in small and medium enterprises \&amp;\#x2014; a Singapore context', in IEEE International Conference on Industrial Engineering and Engineering Management, IEEE, pp.1592-1596, doi: 10.1109/IEEM.2013.6962678.

Yamamoto, Y. and Bellgran, M. (2010) 'Fundamental mindset that drives improvements towards lean production', Assembly Automation, Vol. 30, No. 2, pp.124-130, doi: 10.1108/ 01445151011029754. 
2018-06-08

\title{
Organizational culture aspects that facilitate lean implementation: a pilot study
}

\author{
Alkhoraif, Abdullah
}

Inderscience

Abdullah Alkhoraif and Patrick McLaughlin. Organizational culture aspects that facilitate lean implementation: a pilot study. International Journal of Agile Systems and Management, Volume 11, Issue 2, 2018, pp.103-125 http://dx.doi.org/10.1504/IJASM.2018.10012787

Downloaded from Cranfield Library Services E-Repository 